\title{
OLHARES E HORIZONTES
}

\section{Andréa Figueiredo Leão Grants \\ Gizelle Kaminski Corso \\ Izabele Cristini da Silva \\ Jair Zandoná \\ Leticia Goellner \\ Stélio Furlan \\ Universidade Federal de Santa Catarina}

Fundada em 1993, Anuário de Literatura (vinculada ao Programa de Pós-Graduação em Literatura, da Universidade Federal de Santa Catarina) chega ao vigésimo sétimo número (v.19, $\left.\mathrm{n}^{\circ} 1,2014\right)$ contando com a colaboração de um vigoroso corpo de agentes, entre pesquisadores docentes e estudantes vinculados a Programas de Pós-Graduação, o que assegura não só a periodicidade, com diversidade institucional, como também define o perfil acadêmico deste periódico.

Este número se tece com um conjunto de vinte artigos, entre os de temas livres e os que integram a seção temática Coleções Literárias: textos/imagens. O primeiro artigo "Da centralidade política à centralidade do corpo transumano: movimentos da terceira virada distópica na literatura", de Eduardo Marks de Marques, tem por objetivo uma análise das mudanças encontradas na literatura distópica de língua inglesa ao longo do século XX, a partir dos escritos de Fredric Jameson sobre ficção científica e utopia, destacando elementos para pensar criticamente a condição humana na contemporaneidade.

No segundo artigo, intitulado "No cruzamento de poesia e canção, aprende-se "samba no colégio"”, de Juracy Assmann Saraiva, Gabriela Hoffmann Lopes e Tatiane Kaspari, apostam na hipótese de que a inclusão de canções da música popular brasileira em disciplinas que se voltam para o estudo da Língua e da Literatura pode ser uma estratégia produtiva para despertar o interesse dos discentes pela análise, interpretação e fruição da poesia. Em seguida, em "A leitura: entre expectativa e memória", Annabela Carvalho Rita discute o modo pelo 
qual os paratextos (capa, título, epígrafe, citação) condicionam a atitude de leitura, provocam expectativas e contribuem para a recepção da obra como "objecto estético" (ou não...).

$\mathrm{Na}$ sequência, seguem os artigos "Leitura e tecnologia: formando leitores em uma escola rural", de Maire Josiane Fontana, que apresenta sua pesquisa de cunho bibliográfico, com base nos pressupostos teóricos de Judith Langer sobre a construção de representações e de Michèle Petit, sobre a importância da leitura para a formação humana e para a inclusão social, aliada a uma pesquisa-ação cujo resultado é uma reflexão sobre a formação de leitores multimidiais no ambiente escolar; e "Letramento literário: formação do leitor de literatura em tempos de transição paradigmática, de Francisco Neto Pereira Pinto, objetiva discutir, do ponto de vista teórico, as imagens de leitor de literatura promovidas por alguns trabalhos que se ocupam do conceito de letramento literário. Enfim, fechando esta seção, em "Razão e loucura no conto Gravata", de Caio Fernando Abreu, Ana Paula Cantarelli, avalia este conto com base nos estudos do filósofo Karel Kosik.

Organizada pela professora Maria Aparecida Barbosa, vinculada ao Programa de Pós-Graduação em Literatura da Universidade Federal de Santa Catarina, a seção temática Coleções Literárias: textos/imagens apresenta uma série de reflexões que abarca desde a potência do conceito imagem, diálogos interartes, as relações entre a linguagem literária e cinematográfica, à reflexão sobre o esgotamento da vanguarda cubista e/ou suas disseminações e revivescências, passando pela importância da materialidade de um acervo. Este último tema define os propósitos do artigo "Jorge Amado e o Partido Comunista: papéis avulsos (1941-1942)”, de Tânia Regina Oliveira Ramos. Também compõem esta seção os seguintes artigos: "A Maleta de Bruce Chatwin, Cifra da História”, de Kelvin Falcão Klein; "A antessala de Siegfried Kracauer e Cees Nooteboom: Memória, história e imagem”, de Samanta Lopes Bergé; “As fotografias de Aby Warburg na América: índios, imagens e ruínas, Claudia Mattos", de Joseph Imorde; "Sganzerla Cover", de Victor da Rosa; "Miguel Covarrubias e Andrés Guevara: a influência do cubismo na ilustração editorial do início do século XX", de Daniel Bueno; "Vanguardas e esgotamento: as tensões do moderno em dois artistas", de Maria Salete Borba, Rita Lenira de Freitas Bittencourt; "Rilke e Michelângelo. Pietà: poema de pedra, escultura de palavras", de Jardel Dias Cavalcanti; "Rainer Maria Rilke e Vilhelm Hammershøi sobre a relação entre a pintura e a poesia na virada ao século XX", de Steffen Arndal.

O presente número se fecha com a resenha intitulada "O teatro da Cia. A Rã Qi Ri atado aos 'nós' da palavra", de Ligia K.M. Andrade. Resta agradecer a todas as pessoas que 
auxiliaram na tessitura das malhas da letra desta revista, em especial à Maria Aparecida Barbosa pela proposição, recolha e apresentação dos estudos que compuseram a seção temática; ao Daniel Bueno pela imagem da capa, intitulada Olhar no horizonte, especialmente desenhada para este número, importante paratexto que sugere reverberações da vanguarda cubista no contemporâneo. E que tudo isso anime o encanto numeroso das leituras!

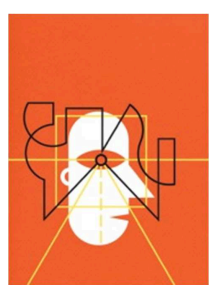

